\title{
Corkscrew collaterals in Raynaud's syndrome
}

\author{
Yuichi Fujii, ${ }^{1}$ Hiroki Teragawa, ${ }^{1}$ Yasuki Kihara, ${ }^{2}$ Yukihito Higashi ${ }^{3}$
}

${ }^{1}$ Department of Cardiovascular Medicine, JR Hiroshima Hospital, Hiroshima, Japan ${ }^{2}$ Department of Cardiovascular Medicine, Hiroshima University Graduate School of Biomedica and Health Sciences, Hiroshima, Japan

${ }^{3}$ Department of Human Genetics, Research Institute for Radiation Biology and Medicine, Hiroshima University, Hiroshima, Japan

\section{Correspondence to}

Dr Yuichi Fujii,

yfujii.64@gmail.com

Accepted 22 April 2016
CrossMark

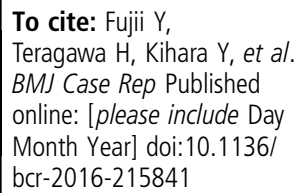
BMJ Case Rep Published online: [please include Day Month Year] doi:10.1136/ bcr-2016-215841

\section{DESCRIPTION}

Raynaud's syndrome (RS) is an episodic peripheral vasospasm induced by cold stress. It is important to distinguish secondary obstructive RS from primary vasospastic RS because the former is associated with a poor prognosis. However, there is no consensus test for distinguishing secondary from primary RS.

We describe a case of a 64-year-old woman who presented with pain and cyanosis in her fingertips on exposure to the cold (figure 1). She was weakly positive for antinuclear antibodies but did not fulfil

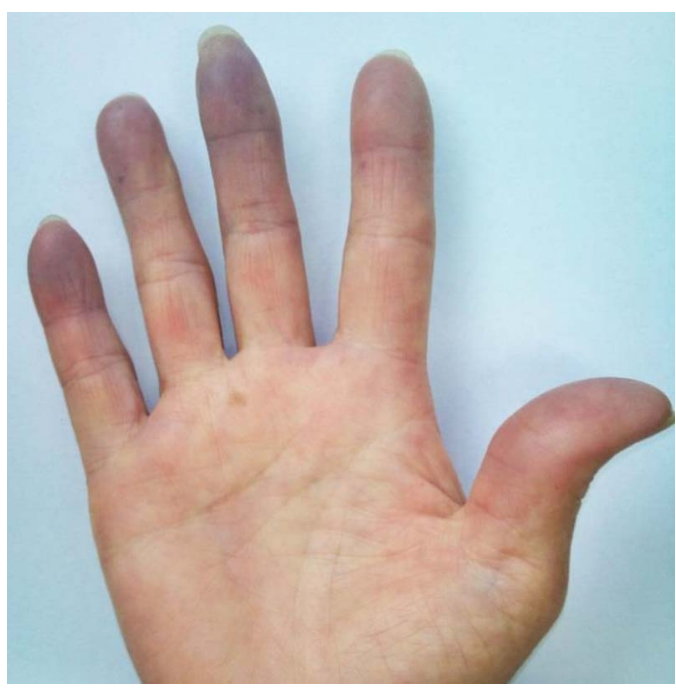

Figure 1 Cyanosis was observed in the fingertips on exposure to cold.

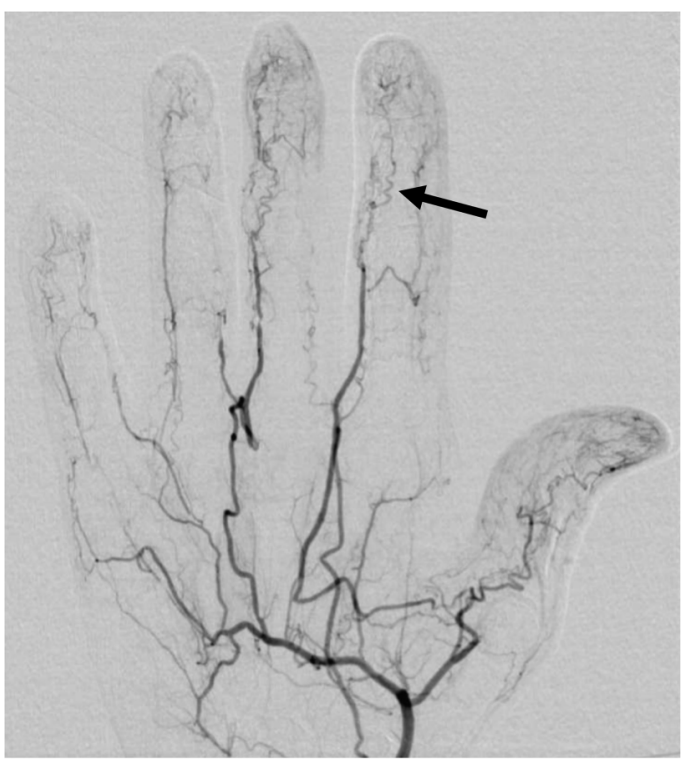

Figure 2 Digital subtraction angiography showing occlusions of digital arteries, with corkscrew collaterals (arrow).

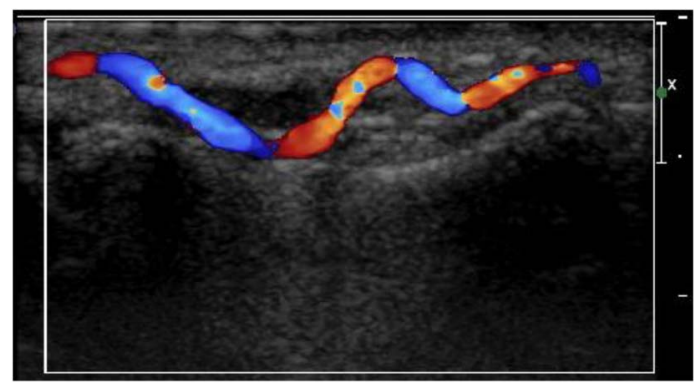

Figure 3 Corkscrew collaterals were detected by colour duplex ultrasonography.

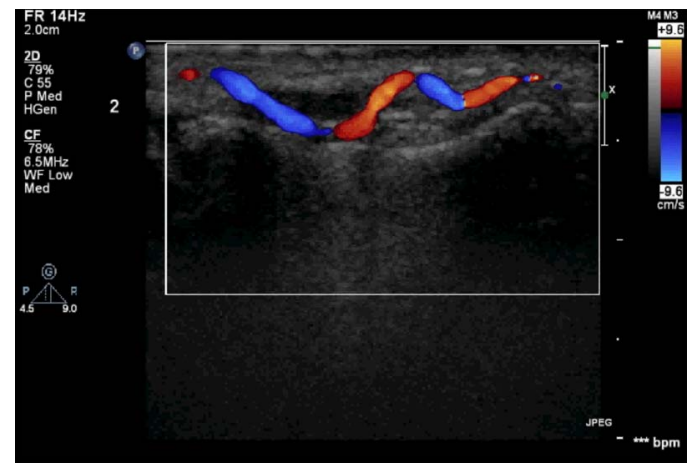

Video 1 Corkscrew collaterals were detected by colour duplex ultrasonography.

the diagnostic criteria for connective tissue diseases. Early treatments, including medication with a calcium channel blocker and prostaglandin analogues, did not improve her symptoms. Digital subtraction angiography revealed multiple occlusions of the digital arteries, with corkscrew collaterals surrounding the avascular area (figure 2, black arrow). Corkscrew collateral arteries in the digit of the right hand were able to be visualised as a snake sign, using duplex ultrasonography (figure 3, video 1). Recently, ultrasonography has been in use to identify corkscrew collaterals that develop after an occlusion of the main trunk. ${ }^{1} 2$ Their existence in patients with RS indicates secondary obstructive RS. Colour duplex ultrasonography is useful for the diagnosis of primary and secondary RS.

\section{Learning points}

- Corkscrew collateral arteries in digits can be visualised by colour duplex ultrasonography.

- Colour duplex ultrasonography is useful for the diagnosis of primary and secondary Raynaud's syndrome. 
Contributors $Y F$ and $Y K$ contributed to drafting the article and conception of this study; HT was involved in performing the angiography; YF was involved in performing the duplex ultrasonography; YF and YH contributed to revising the article critically for important intellectual content.

Competing interests None declared.

Patient consent Obtained.

Provenance and peer review Not commissioned; externally peer reviewed.

\section{REFERENCES}

1 Fujii Y, Nishioka K, Yoshizumi M, et al. Images in cardiovascular medicine. Corkscrew collaterals in thromboangitis obliterans (Buerger's disease). Circulation 2007;116: e539-40.

2 Heil M, Schaper W. Influence of mechanical, cellular, and molecular factors on collateral artery growth (arteriogenesis). Circ Res 2004;95:449-58.

Copyright 2016 BMJ Publishing Group. All rights reserved. For permission to reuse any of this content visit http://group.bmj.com/group/rights-licensing/permissions.

BMJ Case Report Fellows may re-use this article for personal use and teaching without any further permission.

Become a Fellow of BMJ Case Reports today and you can:

- Submit as many cases as you like

- Enjoy fast sympathetic peer review and rapid publication of accepted articles

- Access all the published articles

- Re-use any of the published material for personal use and teaching without further permission

For information on Institutional Fellowships contact consortiasales@bmjgroup.com

Visit casereports.bmj.com for more articles like this and to become a Fellow 